\title{
Evaluation factors for determining the quality of life of physically independent elderly
}

\section{Avaliação de fatores determinantes da qualidade de vida de idosos fisicamente independentes}

\author{
Viviane de Souza Pinho Costa', Mário Molari², João Paulo Manfré dos Santos ${ }^{3}$, Eliane Regina Sernache de Freitas ${ }^{3}$, \\ Rubens Alexandre da Silva Jr', Karen Barros Parron Fernandes ${ }^{4}$
}

\begin{abstract}
Introduction: Brazil has experienced an epidemiological transition process, characterized by an aging population, with a rise in chronic diseases and reduction in infectious diseases. In this context, aging brings about the presence of multimorbidities and the use of multiple drugs associated with a worse quality of life of those people. Objectives: To analyze the determinants of quality of life in physically independent elderly. Method: Cross-sectional study of 498 elderly physically independent, divided into three groups according to the presence of comorbidities: I) Control group: no comorbidities; II) Group comorbidities: <3 comorbidities; and III) multimorbidities Group: $\geq 3$ comorbidities and were also stratified on the use of medications in: I) Control group: non-medicated; II) medicated Group: $<3$ drugs; and III) polymedicated Group: $\geq 3$ drugs. Structured questionnaires were applied to survey data on socio-demographic characteristics, history of comorbidities and medication use, as well as the SF-36 questionnaire as a quality of life assessment method. Results: Statistically significant differences were found in the quality of life regarding gender, educational level, economic status and multimorbidities. The results show that in elderly populations there is inequality in non-white races and among women in matters regarding access to health services. These groups show bigger probability to have more serious chronic conditions and a bad perception of health and quality of life. It is also very clear that in third world countries, a lot of elderly live in poverty having difficulties in the area of health, a major challenge to the implementation of public policies for the care of those people. Lastly, the results make it evident that the aging process has a direct relationship to the amount of installed diseases and increased use of medications. Conclusion: As much as the results showed that the decline of quality of life in physically independent elderly is related to the presence of multimorbidities and high medication intake, researchers state that people can age with a good quality of life if they opt for a successful aging process where significant activities gain space along with daily actions.
\end{abstract}

Keywords: Quality of life, Medication use, Elderly, Elderly health, Rehabilitation.

\section{RESUMO}

Introdução: O Brasil tem passado por um processo de transição epidemiológica, caracterizado por um envelhecimento populacional, com um aumento das doenças crônico-degenerativas e redução das doenças infectocontagiosas. Nesse contexto, o envelhecimento ocasiona a presença de multimorbidades e uso de múltiplos fármacos os quais estão associados a uma pior qualidade de vida dessas pessoas. Objetivos: Analisar os fatores determinantes da qualidade de vida de idosos fisicamente independentes. Método: Estudo transversal com 498 idosos fisicamente independentes, alocados em três grupos quanto à presença de comorbidades: I) Grupo controle: sem comorbidades; II) Grupo comorbidades: < 3 comorbidades; e III) Grupo multimorbidades: $\geq 3$ comorbidades e também estratificados quanto à utilização de medicamentos em: I) Grupo controle: não medicado; II) Grupo medicado: < 3 medicamentos; e III) Grupo polimedicado: $\geq 3$ medicamentos. Foram aplicados questionários estruturados para levantamento de dados sobre características sociodemográficas, história de comorbidades e consumo de medicamentos, além do questionário SF-36 como um método de avaliação de qualidade de vida. Resultados: Foram encontradas diferenças estatisticamente significantes na qualidade de vida em relação ao gênero, escolaridade, classificação econômica e presença de multimorbidades. Os resultados mostram que nas populações idosas existe uma desigualdade nas raças não brancas e no sexo feminino nas questões referentes ao acesso a serviços de saúde, estando estes grupos mais próximos a terem condições crônicas mais graves e mostrando ter uma percepção ruim sobre a saúde e qualidade de vida. Também é muito evidente que em países de terceiro mundo, uma grande quantidade de idosos vive em situação de pobreza apresentando dificuldades no domínio da saúde, sendo um grande desafio a implementação de políticas públicas para o atendimento dessas pessoas. Enfim, os resultados deixam claro que o processo de envelhecimento tem uma relação direta com a quantidade de doenças instaladas e aumento do uso de medicamentos. Conclusão: Por mais que os resultados mostraram que a piora na qualidade de vida em idosos fisicamente independentes está relacionada à presença de multimorbidades e alto consumo de medicamentos, pesquisadores nos esclarecem que as pessoas podem envelhecer com uma boa qualidade de vida se optarem por um envelhecimento bem sucedido onde as atividades significativas ganham espaço junto nas ações da vida diária.

Palavras-chave: Qualidade de vida, Uso de Medicamentos, Idoso, Saúde do Idoso, Reabilitação.

Corresponding author: Viviane de Souza Pinho Costa. Center for Health Science Research of Northern Paraná University (UNOPAR), Marselha Street, 591, Jardim Piza, Zip Code: 86041-140, Londrina (PR), Brazil. Phone: (43) 3371-9848 / (43) 9649 1500. E-mail: vivicosta74@gmail.com

${ }^{1}$ Master Program in Rehabilitation Sciences (UEL/UNOPAR), Londrina (PR), Brazil; Biological and Health Sciences Center, Universidade Norte do Paraná (UNOPAR), Londrina (PR), Brazil.

Financial support: Fundação Nacional de Desenvolvimento do Ensino Superior Particular (FUNADESP).

Submission date 3 September 2015; Acceptance date 2 December 2015; Online publication date 15 December 2015 


\section{INTRODUCTION}

In the new century, numerous demographic changes have been taking place across the planet, and the ratio projection of people aged 60 or more has been growing faster than any other age group. According to the United Nations, the number of seniors increased from $9.2 \%$ in 1990 to $11.7 \%$ in 2013 , with a growth estimate to $21.1 \%$ in $2050 .{ }^{(1)}$ Brazil has presented a sharp aging population process since the beginning of the 20th century, in 1940, the country had in absolute terms less than one million elderly, with life expectancy of around 46 yearss; at the end of that century, in 2000, it reached the total of 9.3 million and it will have reached 49 million by 2050 .

These advances on the issue of longevity in several parts of the world are not granted only to the advances in medicine, decline in mortality rate in all ages, reduced fertility, but also to factors related to actions in public health funded by government programs where these, apart from offering adequate treatment, also create actions that foster disease prevention campaigns arising from daily habits. Such campaigns also encourage health awareness and education related to health issues throughout life, as in the case of Japan, which, according to Shibuya et al.,(2) has been implementing in recent decades these strategies of governmental actions and, as stated by $\mathrm{WHO}^{(3)}$, is among the countries with the highest average life expectancy in the world.

On the other hand, we can only discuss issues that cause us to reflect on how to balance a future in which the number of elderly will be equivalent to that of young people. In this sense, the challenge is not only on survival issues, but also on aspects able to create opportunities to a successful aging process for better life conditions to those people, having improved development logistics of modern societies with structural policies favouring more dynamic spaces where older people can be seen as part of the workforce providing economic benefits to the country, as well as promoting health and well-being in old age, creating supportive and enabling environments so that seniors feel safe. ${ }^{(4)}$

Many factors influence the aging process, causing elderlies to have or not quality of life in terms of basic needs satisfaction, such as housing, health care and medication control ${ }^{(5)}$. Some of these aspects are not of personal responsibility, in other words, satisfactory old age does not depend on individual actions alone, but on the interactions among people living in the same environment ${ }^{(6)}$ as well as on governmental actions, for a successful aging process is more than rights or privileges offered by the society, it is, in fact, a matter of ensuring of keeping - in a healthy way - physical and cognitive health and to be involved in the actions of daily life, even with inevitable aging limitations, the elderly must learn to live a productive life. ${ }^{(7)}$

Another determining factor in old age is the emergence of multimorbidity throughout life cycle, that is the presence of three or more chronic diseases which are associated with mortality rate, disability and lack of autonomy among other factors that cause functional decline in the last decade or yearss of life ${ }^{(8)}$, especially when elderlies make regular use of several drugs that increase the risk of adverse effects ${ }^{(9)}$, and consequently cause permanent dependence and a negative impact on psychological and social aspects of quality of life. ${ }^{(8,10)}$

Although several studies have reported the impact of socio-demographic and cultural aspects on the quality of life, few studies have evaluated the interaction of these factors with the presence of multimorbidities and/ or the use of various drugs on the quality of life of older people. Thus, this study aimed to analyze the determinants of quality of life of physically independent elderly.

\section{METHOD}

\section{Ethical procedures}

This study was approved by the UNOPAR Research Ethics Committee (PP 0070/09). All subjects were informed on the methodology and objectives and signed a free and informed consent prior to study enrollment.

\section{Research Study Design and Study Population}

Descriptive cross-sectional study attended by 498 elderly patients (aged $\geq 60$ yearss) physically independent according to criteria of Spirduso ${ }^{(11)}$ members of the project "Study of Aging and Longevity" (EELO Project). The elderly were stratified into three groups for the presence of comorbidities: I) Control group: no comorbidities; II) Group comorbidities: <3 comorbidities; III) multimorbidades Group: $\geq 3$ comorbidities.

Seniors were also stratified on the use of medicines in: I) Control group: non-medicated; II) medicated Group: $<3$ drugs; III) polimedicado Group: $\geq 3$ drugs.

\section{Data collection}

During data collection, structured questionnaires were used for survey data on socio-demographic characteristics (sex, age, education, economic status, race and condition of life), history of comorbidities and medication use.

We used the SF-36 (Medical Outcomes Study 36-Form Health Survey) as a method of assessing quality of life. This instrument was developed in the late 80 s in the US and has been applied in various situations with good sensitivity. It has been translated and validated for the Brazilian population and it is characterized by a multidimensional questionnaire consisting of 36 items, grouped in eight scales or components: physical functioning, pain, general health, condition, social and emotional aspects and mental health. It features a score between 0-100 points, where zero corresponds to the worst general health status and 100 to the best general health status. ${ }^{(12)}$ 


\section{Statistical analysis}

Data were analyzed using the Statistical Package for Social Sciences (SPSS) programme, version 15.0, both descriptively and analytically. A 95\% confidence interval and a significance level of $5 \%$ ( $p<0.05)$ were adopted for all applied tests. After Shapiro-Wilk normality test, variance analysis was used (Bonferroni post-test) for comparison between groups regarding medication use the presence of comorbidities concerning the domains of the SF-36.

Yet, to indicate the determinants of quality of life we used a multivariate analysis (Poisson regression). Sociodemographic characteristics (age, gender, education, economic status, race and condition of life), the presence of multimorbidades and consumption of drugs were considered as independent variables. Then again, the dependent variables were: physical and mental components of quality of life. In order to calculate the components of the SF-36, we considered factors such as functional capacity, pain and limitations associated to physical problems concerning overall health for calculating the physical component of quality of life (PC). And for mental health, limitations due to emotional problems and vitality-related social aspects for calculating the mental component of quality of life (CM). ${ }^{(12)}$

To assess the association between independent and dependent variables, the distribution mean of the population was observed in each of these components and subsequently the determining factors were classified as high or low impact on quality of life (lower or higher values to the values of average population, respectively).

\section{RESULTS}

1) Influence evaluation of multimorbidity and multiple drugs in the quality of life for seniors

We assessed 493 elderly, and the characterization of the study sample is presented in Table 1.

It was noted that people with multimorbidities (> 3 comorbidities) presented a worse score in the different domains of quality of life - functional capacity, limitations due to physical aspects, pain, general health condition, vitality, social aspects, emotional limitations and mental health - when compared to the control group and the group that shows up to 03 comorbidities (Variance Analysis followed by Bonferroni post-test). On the other hand, no differences were observed between the control group and up to 03 comorbidities - these data are displayed in Table 2.

2) Impact of socio-demographic factors, multimorbidity and polypharmacy interaction on the physical component in the quality of life of sênior citizens.

In the univariate analysis, we found that age, gender, economic status, educational level, living conditions, multimorbidities and polypharmacy had impact on the physical component of quality of life for seniors. However, race does not influence the physical component of quality of life. In the multivariate model (Poisson regression) the variables that remained associated were: gender, education and presence of multimorbidities. Data regarding the impact of the independent variables on the physical component of quality of life are shown in Table 3.

3) Socio-demographic factors, multimorbidity and polypharmacy interaction impact on mental component of seniors quality of life.

In the univariate analysis, we found that age, gender, economic status, living conditions, multimorbidities and polypharmacy had an impact on the mental component of quality of life for seniors. However, in the multivariate model (Poisson regression) the variables that remained

Table 1. Characteristics of the sample.

\begin{tabular}{|c|c|c|}
\hline & $\begin{array}{l}\text { Absolute frequency } \\
\text { (n) }\end{array}$ & $\begin{array}{c}\text { Relative frequency } \\
\text { (\%) }\end{array}$ \\
\hline \multicolumn{3}{|l|}{ Sex } \\
\hline Male & 166 & 33.7 \\
\hline Female & 327 & 66.3 \\
\hline \multicolumn{3}{|l|}{ Age Group } \\
\hline $60-64$ years & 122 & 24.7 \\
\hline $65-75$ years & 281 & 57.0 \\
\hline$>75$ years & 90 & 18.3 \\
\hline \multicolumn{3}{|l|}{ Skin color } \\
\hline White & 306 & 62.1 \\
\hline No white & 187 & 37.9 \\
\hline \multicolumn{3}{|l|}{ Education } \\
\hline Up to 4 years of study & 398 & 80.7 \\
\hline Above to 4 years of study & 95 & 19.3 \\
\hline \multicolumn{3}{|l|}{ Economic class } \\
\hline$A+B$ & 82 & 16.6 \\
\hline C & 317 & 64.3 \\
\hline$D+E$ & 94 & 19.1 \\
\hline \multicolumn{3}{|l|}{ Living conditions } \\
\hline With partner or family & 320 & 64.9 \\
\hline Alone & 173 & 35.1 \\
\hline \multicolumn{3}{|l|}{$\begin{array}{l}\text { Presence of } \\
\text { multimorbidities }\end{array}$} \\
\hline No comorbidities & 40 & 8.1 \\
\hline Until 3 comorbidities & 192 & 38.9 \\
\hline$>3$ comorbidities & 261 & 52.9 \\
\hline \multicolumn{3}{|l|}{ Consumption of drugs } \\
\hline Do not use & 109 & 22.1 \\
\hline$<3$ drugs & 163 & 33.1 \\
\hline$>3$ drugs & 221 & 44.8 \\
\hline
\end{tabular}


Table 2. Distribution domains of quality of life for the presence of multimorbidities and drug consumption.

\begin{tabular}{|c|c|c|c|c|}
\hline \multirow{2}{*}{ Domains } & \multicolumn{3}{|c|}{ Multimorbidities } & \multirow{2}{*}{$\mathbf{P}$} \\
\hline & No comorbidities & Until 3 comorbidities & $>3$ comorbidities & \\
\hline Functional Capacity & $91.25 \pm 18.07$ & $81.92 \pm 20.73$ & $59.86 \pm 30.84$ & 0.0001 \\
\hline $\begin{array}{l}\text { Limitation for Physical } \\
\text { Problems }\end{array}$ & $76.25 \pm 18.79$ & $73.07 \pm 39.74$ & $52.68 \pm 44.31$ & 0.0001 \\
\hline Pain & $80.00 \pm 23.96$ & $69.77 \pm 26.44$ & $54.44 \pm 29.77$ & 0.0001 \\
\hline General Health & $79.42 \pm 18.06$ & $70.73 \pm 21.47$ & $63.39 \pm 21.45$ & 0.0001 \\
\hline Vitality & $78.25 \pm 17.08$ & $69.76 \pm 23.18$ & $61.40 \pm 24.00$ & 0.0001 \\
\hline Social Aspects & $91.36 \pm 16.05$ & $84.80 \pm 21.95$ & $75.20 \pm 26.88$ & 0.0001 \\
\hline $\begin{array}{l}\text { Limitation for Emotional } \\
\text { Aspects }\end{array}$ & $68.39 \pm 41.25$ & $68.39 \pm 41.88$ & $58.09 \pm 44.32$ & 0.031 \\
\hline Mental health & $85.30 \pm 20.80$ & $78.30 \pm 20.07$ & $67.41 \pm 25.65$ & 0.0001 \\
\hline \multirow{2}{*}{ Domains } & \multicolumn{3}{|c|}{ Consumption of drugs } & \\
\hline & Do not use & Until 3 drugs & $>3$ drugs & \\
\hline Functional Capacity & $82.43 \pm 22.73$ & $77.85 \pm 23.72$ & $60.31 \pm 31.61$ & 0.0001 \\
\hline $\begin{array}{l}\text { Limitation for Physical } \\
\text { Problems }\end{array}$ & $67.66 \pm 42.53$ & $71.50 \pm 41.23$ & $53.39 \pm 43.69$ & 0.0001 \\
\hline Pain & $71.14 \pm 28.27$ & $66.06 \pm 27.85$ & $55.58 \pm 29.62$ & 0.0001 \\
\hline General Health & $74.92 \pm 20.60$ & $69.24 \pm 20.13$ & $62.67 \pm 22.29$ & 0.0001 \\
\hline Vitality & $70.68 \pm 22.29$ & $67.94 \pm 23.31$ & $62.31 \pm 24.34$ & 0.005 \\
\hline Social Aspects & $82.79 \pm 22.70$ & $84.11 \pm 22.49$ & $76.16 \pm 27.03$ & 0.004 \\
\hline $\begin{array}{l}\text { Limitation for Emotional } \\
\text { Aspects }\end{array}$ & $64.23 \pm 43.66$ & $67.26 \pm 42.14$ & $59.11 \pm 43.96$ & 0.18 \\
\hline Mental health & $77.67 \pm 21.87$ & $75.36 \pm 20.64$ & $69.19 \pm 26.74$ & 0.004 \\
\hline
\end{tabular}

associated were: gender, economic status and presence of multimorbidades. Data regarding the impact of the independent variables on the mental component of quality of life are shown in Table 4.

\section{DISCUSSION}

Several sociodemographic characteristics have an impact on the quality of life of elderly people. ${ }^{(6,10)}$ Although there are reports that older people have worse quality of life $\mathrm{e}^{(13,14)}$, these data were not observed in this study. This could be explained because differences in the presence of multimorbidities in relation to age were not noticed.

In the present study it was observed that women have worse quality of life compared to men in both physical and mental aspects. Studies show that the fact that women have a lower welfare than men is related to cultural aspects of each country or even among regions within the same country. In studies by Tajvar, Arab and Montazeri(15) in Tehran women have less access to information, education and employment and in general have a drawback in economic status and social position compared to those of men. Studies in other countries on quality of life, as in the case of Finland, Taiwan, Poland and Croatia, Japan and Korea report that women are a less privileged group compared to male groups. ${ }^{(14)}$ A major point in the study of the quality of life of older people is associated with races, since society coexists with tremendous exclusion and social inequalities of various social groups causing them to have poor social work and healthcare system compared to some other populational groups.

Several surveys show that non-white seniors have shown more symptoms and more chronic conditions than white elderlies $^{(15)}$, as many nonwhites have less access to health services. In addition, they also show to have a bad perception about their health and quality of life ${ }^{(16)}$, unlike what was found in this study.

Although initially observed in this study that older adults with low socioeconomic status had a worse quality of life in both physical and mental aspects, these data were not confirmed in the multivariate analysis.

In third world countries, generally speaking, people living in poverty have several difficulties concerning health issues, especially the elderly, since development and implementation of healthcare public policies for this population poses a major challenge to public health. ${ }^{(13)}$ 
Table 3. Relationship between sociodemographic factors, multimorbidity and polypharmacy in the elderly physical component of quality of life.

\begin{tabular}{|c|c|c|c|c|c|c|}
\hline \multirow{2}{*}{ Variables } & \multicolumn{3}{|c|}{ Univariate analysis } & \multicolumn{3}{|c|}{ Multivariada analysis } \\
\hline & PR unadjusted & $\mathrm{Cl}(95 \%)$ & $p$ & PR adjusted & $\mathrm{Cl}(95 \%)$ & $p$ \\
\hline \multicolumn{7}{|c|}{ Aged Group } \\
\hline $60-69$ years & 1 & - & - & 1 & - & - \\
\hline $70-79$ years & 1.23 & $0.99-1.52$ & 0.05 & 1.01 & $0.91-1.12$ & 0.82 \\
\hline$>80$ years & 1.22 & $0.84-1.77$ & 0.29 & 1.07 & $0.94-1.21$ & 0.33 \\
\hline \multicolumn{7}{|c|}{ Sex } \\
\hline Male & 1 & - & - & 1 & & \\
\hline Female & 1.68 & $1.29-2.18$ & $0.0001^{*}$ & 1.12 & $1.02-1.23$ & $0.02 *$ \\
\hline \multicolumn{7}{|c|}{ Skin Color } \\
\hline White & 1 & - & - & - & - & - \\
\hline No White & 1.05 & $0.96-1.14$ & 0.33 & - & - & - \\
\hline \multicolumn{7}{|c|}{ Economic class } \\
\hline$A$ e $B$ & 1 & - & - & 1 & - & - \\
\hline C & 1.09 & $0.97-1.23$ & 0.12 & 1.00 & $0.89-1.13$ & 0.97 \\
\hline De E & 1.17 & $1.02-1.36$ & $0.02 *$ & 1.00 & $0.86-1.16$ & 0.98 \\
\hline \multicolumn{7}{|c|}{ Living conditions } \\
\hline $\begin{array}{l}\text { With partner or } \\
\text { family }\end{array}$ & 1 & - & - & 1 & - & - \\
\hline Alone & 1.11 & $1.01-1.21$ & 0.03 & 1.03 & $0.94-1.14$ & 0.47 \\
\hline \multicolumn{7}{|c|}{ Education level } \\
\hline$>4$ years of study & 1 & - & - & 1 & - & \\
\hline $\begin{array}{c}\text { Until } 4 \text { years of } \\
\text { study }\end{array}$ & 1.15 & $1.04-1.28$ & 0.007 & 1.13 & $1.01-1.27$ & $0.03 *$ \\
\hline \multicolumn{7}{|c|}{ Presence of multimorbidities } \\
\hline No comorbidities & 1 & - & - & 1 & - & - \\
\hline $\begin{array}{c}\text { Until } 3 \\
\text { comorbidities }\end{array}$ & 1.11 & $0.97-1.27$ & 0.11 & 1.13 & $0.97-1.32$ & 0.11 \\
\hline$>3$ comorbidities & 1.47 & $1.29-1.68$ & $0.0001^{*}$ & 1.38 & $1.17-1.64$ & $0.0001 *$ \\
\hline \multicolumn{7}{|c|}{ Consumption of drugs } \\
\hline Do not use & 1 & - & & 1 & - & - \\
\hline$<3$ drugs & 1.03 & $0.92-1.15$ & 0.56 & 0.94 & $0.83-1.06$ & 0.30 \\
\hline$>3$ drugs & 1.29 & $1.16-1.44$ & $0.0001 *$ & 1.04 & $0.91-1.20$ & 0.52 \\
\hline
\end{tabular}

*statistically significant.

Many countries, as in the case of Iran, the majority of elderly people are poor and their income often does not adequately cover their expenses, especially in the case of older women, who culturally face various identity issues in their region, adversely influencing their quality of life. ${ }^{(17)}$

According to gerontologists, solid financial management and investment in education throughout their lives will provide a more satisfactory aging process with greater well-being, because economic status is an indicator of higher relevance of the quality of life in the aging process, compared to other examined factors ${ }^{(18)}$. In this study, no association was observed between education and quality of life, disagreeing with the study of Lasheras et al., ${ }^{(19)}$ which describes that older people with low educational level show more association of unhappiness, poor social relationships, poor health and lower quality of life.

It was initially observed that elderly people living alone have a poorer life quality, however, these data were not confirmed in multivariate analysis. On the other hand, Vahdainia et al., ${ }^{(20)}$ found that elderly people living with their spouses show to have a higher QoL in all domains of the SF-36 compared to those older people who are widows and divorcees.

However, there are conflicting reports in which it is shown that seniors living with relatives have a worse quality of life than those living alone ${ }^{(18)}$. Perhaps this is because leaving their 
Table 4. Relationship between socio- demographic factors, multimorbidity and polypharmacy in the mental component of quality of life of seniors.

\begin{tabular}{|c|c|c|c|c|c|c|}
\hline \multirow{2}{*}{ Variables } & \multicolumn{3}{|c|}{ Univariate analysis } & \multicolumn{3}{|c|}{ Multivariada analysis } \\
\hline & PR unadjusted & $\mathrm{Cl}(95 \%)$ & $p$ & PR adjusted & $\mathrm{Cl}(95 \%)$ & $p$ \\
\hline \multicolumn{7}{|c|}{ Aged Group } \\
\hline $60-69$ years & 1 & - & w & 1 & - & - \\
\hline $70-79$ years & 0.94 & $0.85-1.05$ & 0.26 & 0.96 & $0.87-1.07$ & 0.51 \\
\hline$>80$ years & 0.91 & $0.80-1.04$ & 0.16 & 0.93 & $0.82-1.07$ & 0.30 \\
\hline \multicolumn{7}{|c|}{ Sex } \\
\hline Male & 1 & - & - & 1 & - & - \\
\hline Female & 1.31 & $1.2-1.42$ & $0.0001 *$ & 1.25 & $1.14-1.37$ & $0.0001^{*}$ \\
\hline \multicolumn{7}{|c|}{ Skin Color } \\
\hline White & 1 & - & - & - & - & - \\
\hline No White & 1.02 & $0.93-1.11$ & 0.70 & - & - & - \\
\hline \multicolumn{7}{|c|}{ Economic Class } \\
\hline$A$ e $B$ & 1 & - & - & 1 & - & - \\
\hline C & 1.16 & $1.03-1.30$ & 0.01 & 1.14 & $1.02-1.27$ & $0.02 *$ \\
\hline De E & 1.16 & $1.00-1.34$ & 0.04 & 1.12 & $0.97-1.29$ & 0.13 \\
\hline \multicolumn{7}{|c|}{ Living conditions } \\
\hline $\begin{array}{l}\text { With partner or } \\
\text { family }\end{array}$ & 1 & - & & 1 & - & - \\
\hline Alone & 1.07 & $0.98-1.17$ & 0.15 & 0.99 & $0.90-1.09$ & 0.89 \\
\hline \multicolumn{7}{|c|}{ Education level } \\
\hline$>4$ years of study & 1 & & - & - & - & - \\
\hline $\begin{array}{c}\text { Until } 4 \text { years of } \\
\text { study }\end{array}$ & 1.03 & $0.92-1.15$ & 0.62 & - & - & - \\
\hline \multicolumn{7}{|c|}{ Presence of multimorbidities } \\
\hline No comorbidities & 1 & - & - & 1 & - & - \\
\hline $\begin{array}{c}\text { Until } 3 \\
\text { comorbidities }\end{array}$ & 1.11 & $0.95-1.29$ & 0.18 & 1.13 & $0.96-1.34$ & 0.14 \\
\hline$>3$ comorbidities & 1.30 & $1.19-1.51$ & $0.0001^{*}$ & 1.25 & $1.05-1.50$ & $0.01 *$ \\
\hline \multicolumn{7}{|c|}{ Consumption of drugs } \\
\hline Do not use & 1 & - & - & 1 & - & - \\
\hline$<3$ drugs & 0.99 & $0.88-1.12$ & 0.92 & 0.91 & $0.801-1.03$ & 0.15 \\
\hline$>3$ drugs & 1.16 & $1.04-1.30$ & 0.007 & 0.97 & $0.84-1.13$ & 0.66 \\
\hline
\end{tabular}

*statistically significant.

homes, their own spaces, their roots cause dissatisfaction and also, they culturally end up perceiving they have had an unsuccessful life project. This data could explain the observed discrepancies in the results, since in this study, both the elderly residing with relatives or spouses were grouped into one category.

There is no doubt about the aging process relationship and the perception of quality of life (positive or negative) with the amount of installed diseases and used drugs, a fact observed in this study. Similarly, there are reports of an inverse association between the presence of comorbidities and quality of life ${ }^{(13)}$, a fact corroborated by a systematic review consisted of 30 studies. $^{(21)}$
Nobrega et al., (21) evaluated the association between multimorbidity and quality of life in elderly patients with stable chronic diseases, with a final sample of 104 subjects, and found that with the increasing number of comorbidities, quality of life in sêniors worsened (mainly in the physical, psychological and social aspects). Similar data were also observed by other authors. ${ }^{(22,23,13)}$

Studies on quality of life in elderly patients with multimorbidities are extremely important in the context of public health, since the estimated prevalence of multimorbidity among the elderly ranges from $30 \%$ to $63 \%$ in different developed countries. ${ }^{(13,14)}$ 
However, there are few studies describing the prevalence of multimorbididity in developing countries. In this study, it was observed that the prevalence in the elderly multimorbididity was approximately $53 \%$. The most prevalent chronic diseases in the elderly are hypertension, diabetes, arthritis and cardiovascular diseases directly affecting the perception of quality of life, especially in older people at older ages, as in people over 75 yearss $^{(24)}$, leading us to realize that it is very common for older people to live together with one or more chronic diseases in their last decades.

In this study, individuals with multimorbidity had lower scores in all domains of the SF-36. Furthermore, the presence of multimorbidities had a negative impact on both the physical and mental components of life quality.

The increased prevalence of multimorbidities leads to increased use of polypharmacy with consequent higher risk of adverse effects by the use of drugs ${ }^{(25)}$. We observed that polymedicated patients had lower scores in the different domains of quality of life, except in the limited domain due to emotional problems. Furthermore, it was observed that polymedicated patients have greater impact on the physical and mental life components of quality of life. However, these data were not observed in the multivariate analysis.

According to Nobrega et al., ${ }^{(21)}$ the number of medications used adversely influences the quality of life of patients in the physical domain, and this finding may be possibly related to a higher prevalence of physical inactivity in this population. In this context, families should encourage the elderlies to take up physical activity programs and or physical therapy treatments to promote physical rehabilitation ${ }^{(26)}$, reduce the need for chronic consumption of medicines and counteract the decline in physical condition related to aging, since older people with negative physical conditions are closely related to a sedentary lifestyle in their daily physical activities, which are crucial actions for good life quality and autonomy in the aging process.

It can be concluded that female elderly, of low socioeconomic status and with multimorbidities are those with poorer quality of life. In this context, the importance of adequate public policies for these subgroups of older people is highlighted, especially in developing countries. Finally it can be seen, that not all older seniors are frail or with poor quality of life, but cultural, personal and public poçicies influence have a direct association with those indicators of quality of life.

\section{AUTHORS CONTRIBUTION}

All authors participated in data collection, analysis and writing of the manuscript.

\section{COMPETING INTERESTS}

The authors declare no conflicts of interest.

\section{AUTHOR DETAILS}

${ }^{2}$ Physican educacion, Universidade Estadual de Londrina (UEL), Londrina (PR), Brazil. ${ }^{3}$ Program in Rehabilitation Sciences UEL/UNOPAR, Londrina
(PR), Brazil. ${ }^{4}$ PhD in Rehabilitation Sciences, UEL/UNOPAR; Catholic University of Paraná (PUCPR), Londrina (PR), Brazil.

\section{REFERENCES}

1. United Nations. Economic \&Social Affairs: World Population Ageing 2013. New York: United Nations; 2013. Disponível em: <http://www. un.org/en/development/desa/population/publications/pdf/ageing/ WorldPopulationAgeing2013.pdf>. Acesso em: 20 dez. 2014.

2. Shibuya K, Hashimoto H, Ikegami N. Future of Japan's system of good health at low cost with equity: beyond universal coverage. Lancet. 2011;50(11);1788-1798.

3. WHO. World Health statistics. Parte IIII - Global health indicators: 2014. Disponivel em: <http://www.who.int/gho/publications/world_health_ statistics/EN_WHS2014_Part3.pdf?ua=1>. Acesso em: 19 dez. 2014.

4. ONU. Uma sociedade para todas as idades. Comunicado de imprensa do Departamento de Informação Pública da ONU, símbolo SOC/4619, de 12 de Abril de 2002. Disponível em < https://www.unric.org/html/ portuguese/ecosoc/ageing/idosos-final.pdf>. Acesso em 22 dez. 2014.

5. Minayo MCS, Hartz ZMA, Buss PM. Qualidade de vida e saúde: um debate necessário. Ciênc Saúde Coletiva, Rio de Janeiro. 2000;5(1):7-18.

6. Neri AL. Qualidade de vida e idade Madura. 7 ed. Campinas: Papirus; 2007.

7. Liffiton JA, Horton S, Baker J, Weir P. Successful aging: how does physical activity influence engagement with life? Eur Rev Aging Phys Act, 2012;9(1):103-108.

8. Schäfer I, von Leitner EC, Schön G, Koller D, Hansen H, Kolonko T, et al. Multimorbidity patterns in the elderly: a new approach of disease clustering identifies complex interrelations between chronic conditions. Plos One, São Francisco, California. 2010;5(12):1-10.

9. Lenaghan $E$, Holland $R$, Brooks $A$. Home-based medication review in a high risk elderly population in primary care-the POLYMED randomised controlled Trial. Age and Ageing, London.2007;36(3):292-297.

10. Nahas MV. Atividade física, saúde e qualidade de vida. Midiograf: Londrina; 2013.

11. Spirduso W. Dimensões Física do Envelhecimento. São Paulo: Manole; 2005.

12. Ciconelli RM, Ferraz, MB, Santos W, Meinão I. Quaresma MR. Tradução para a língua portuguesa e validação do questionário genérico de avaliação de qualidade de vida SF-36 (Brasil SF-36). Rev. Bras. Reumatol, Campinas. 1999;39(3):143-150.

13. Fortin M, Dubois MF, Hudon C, Soubhi H, Almirall J, et al. Multimorbidity and quality of life: a closer look. Health and Qualith of Life Outcomes, USA. 2007;5(52):1-8.

14. Britt $\mathrm{HC}$, Harrison $\mathrm{CM}$, Miller GC, Knox SA, et al. Prevalence and patterns of multimorbidity in Australia. MJA, Australia. 2008;189(2):72-77.

15. Tajvar M, Arab M, Montazeri A. Determinants of health-related quality of life in elderly in Tehran, Iran. BMC Public Health. 2008;8(1):323.

14. Lee $Y$, Shinkai SA. A comparison of correlates of self-reported health and function disability of older person in the Far East: Japan and Korea. Archive of Gerontology and Geriatrics, USA. 2003;37(1):63-76.

15. Ferraro K, Farmer M. Double jeopardy to health hypothesis for african american: analysis and critique. J Health Soc Behav,California, Los Angeles. 1996;37(1):27-43.

16. Krause N. Rerceived social support, anticipated support, social class and mortality. Research on Aging, Boston. 1997;19(4):387-422.

17. Kaldi AR. A study on physical, social and mental problems of the elderly in District 13 of Tehran. Age Ageing, London. 2004;33(3):31-39.

18. Bowling A. Aging well, quality of life in older age. Maidenhead: Open University Press; 2005 
19. Lasheras C, Patterson AM, Casado C, Fernandez S, et al. Effects of education on the quality of life, diet, and cardiovascular risk factors in an elderly Spanish community population. Experimental Aging Research, United Kingdom. 2001;27(3):257-270.

20. Vahdani Nia MS, Goshtasebi A, Montazeri A, Maftoon F. Health- related quality of life in an elderly population in Iran: a population-based study. Payesh, Tehran, Iran. 2005;4(2):113-120.

21. Nóbrega TC, Jaluul O, Machado AN, Paschoal SM, Jacob Filho W. Quality of life and multimorbidity of elderly outpatients. Clinics, São Paulo. 2009;64(1):45-50.

22. Wee HL, Cheung YB, Li SC, Fong KY, Thumboo J. The impact of diabetes mellitus and other chronic medical conditions on health-related Quality of Life: is the whole greater than the sum of its parts? Health Qual Life Outcomes. USA. 2005;3(2):67-69.

23. Rijken M, van Kerkhof M, Dekker J, Schellevis FG. Comorbidity of chronic diseases: effects of disease pairs on physical and mental functioning. Qual Life Res, Europa. 2005;14(1):45-55.

24. Aghamolaei T, Tavafian SS, Zare S. Health related quality of life in elderly people living in Bandar Abbas, Iran: a population-based study. Acta medica Iranica, Tehran, Iran. 2010;48(3):185-191.

25. Starfield B. Global health, equity, and primary care. J Am Board Fam Med,USA.2007; 20(1):511-513.

26. Delai K D, Wisniewski MSW. Inserção do fisioterapeuta no Programa Saúde da Família. Ciênc. saúde coletiva [online]. 2011;16(1):1515-1523. 